\title{
Improving Dysfunctional Employee turnover
}

\author{
Effulgence \\ Vol. 17, No. 1 \\ January - June 2019 \\ Rukmini Devi Institute of Advanced Studies \\ E-mail : effulgence@rdias.ac.in, Website : www.rdias.ac.in \\ http://effulgence.rdias.ac.in/user/default.aspx \\ https://dx.doi.org/10.33601/effulgence.rdias/v17/i1/2019/1-15
}

\author{
Ms. Preeti Dwivedi ${ }^{1} \backslash \Delta$ \\ Dr. Vijit Chaturvedi ${ }^{2}$ \\ Dr. J.K. Vashist ${ }^{3}$
}

\begin{abstract}
This research paper focuses on finding and assessing the criteria responsible for making an efficient employee to leave the organization. This research also focuses on finding the preference of the employees for criteria and implementation of appropriate retention model. The research is based on the survey conducted among the selected employees of 10 logistics organizations. 30 highest performing employees i.e. 3 from each organization were selected on the basis of performance appraisal ratings received by them. Analytic Hierarchy Process (AHP) approach is used to identify the importance attached to each criterion and alternatives given by employees. Importance attached to three alternatives was evaluated before and after the implementation of the employee retention model. The study found that career development was the most preferred criterion followed by work-life balance, senior-subordinate relationship, motivation, compensation, organization commitment, Training $\mathcal{E}$ Development and working environment, influencing the decision of employee whether to perform efficiently, stay absent or quit the organization for some better opportunities. Velocity Model of Efficiency (VME) was implemented and was found effective in increasing the level of satisfaction of employees and motivating them to stay longer with the same organization.
\end{abstract}

Keywords: Absenteeism, Dysfunctional employee turnover, Employee Efficiency, Employee Retention, Employee exit, Employee retention models, Employee turnover.

\section{INTRODUCTION}

$\mathrm{T}$ raditional employee retention strategies are more focused on improving the employee turnover of the organization, irrespective of the quality of employee being retained. With increase in the demand for excellence, quality, optimum productivity, efficiency and effectiveness, the organizations are striving hard to recruit, train and sustain the talent. Now the employee retention

1. Head HR department, Road Railer Division, Kirloskar Pneumatic Co. Ltd, India, pdwivedi215@gmail.com

2. Associate Professor, Amity Business School, Amity University, Noida, vijitchaturvedi@gmail.com

3. Chief Executive Officer, Road Railer Division, Kirloskar Pneumatic Co. Ltd, India, jugal.vashist_jan14@bimtech.ac.in 
strategies are more skewed towards retaining the efficient employees. An organization wants to gain the competitive advantage so it is concerned about their existing strategies of retaining the efficient and effective employees (Brown et al., 2013). Retention of employees is the effort of an employer to retain them. It is the ability of any employer to hold their valuable and talented employees for longer period of time from leaving the job (Donoghue 2010). Retaining an efficient employee is a major challenge for organizations now a day as highly skilled employees are leaving the organization at higher rate than the semi-skilled or unskilled employees. That is Dysfunctional employee turnover is higher than the functional employee turnover. As per the report of Mckinsey \& Company, efficient employees are found to be 8 times more productive than the others (Keller, S., and Meaney, M., 2017). Human resource managers are not alone responsible for retention of an efficient employee. Supervisor in coordination with human resource manager should work in direction of retaining the talent.

Employee retention and employee turnover are inversely proportional to each other. Employee turnover occurs when employer fails to engage and retain the employees (Samuel, M. O., and Chipunza, C. 2009). Efficient employees always look for opportunities within the organization or outside the organization, if they do not get the proper recognition. Due to which dysfunctional employee turnover is higher than the functional employee turnover. Employees should be considered and treated as partners or entrepreneur instead of assets of the organization. Entrepreneur acts in the direct of business growth instead of personal growth. Organizations should work in the concept of win win that is employees ensuring the growth of organization and vice versa.

The scope of the research is to improve the dysfunctional employee turnover particularly in logistics sector in India. Supply chain management also called logistics sector is the backbone of any industry. As almost all the industries involves movement of goods and service. Logistics sector is highly unorganized and need immediate attention to retain the skilled force. As per the report of World Bank, losing key managers of the organization can weaken the growth of logistics organizations (McKinnon et al., 2017). Logistics industry in India is booming now. According to Economic Survey 2018, Indian logistics which is worth of USD 160 million going to touch USD 215 billion in coming 2 years. The Indian logistics industry has provided more 22 million jobs in this sector which has grown a rapid rate of $7.8 \%$ during last 5 years (The Economic Times 2018). As the number of employees grew in the organization, it is the firm's responsibility to ensure the growth of its best employee so that they can feel as the part of the organization and employer can gain the competitive advantage.

\section{THEORETICAL BACKGROUND}

Employee turnover can be good and bad for the organization (Dalton et al, 1981). It has been estimated in various studies that losing an efficient employee costs upto five times his salary (Giri, D.M.S.and Mrs. Y. Gayatri. 2018). Employee turnover occurs if either the organization asks the employee to leave the organization or the employee itself leaves the organization. It can be considered as involuntary and voluntary employee turnover respectively (Wallace, J., and Gaylor, K. P. 2012). Further voluntary employee turnover is categorized into dysfunctional and functional employee turnover (Dalton et al., 1981). On the basis of the type of separation from the organization, voluntary employee turnover is categorized as Dysfunctional or functional employee turnover (Wallace, J., and Gaylor, K. P. 2012). Dysfunctional employee turnover occurs when employee wants to leave the organization but the organization wants to retain the employee and functional employee turnover occurs when an employee leaves the organization but the organization is not concerned about the employee exit (Dalton et al, 1981). 


\section{Dysfunctional and Functional employee turnover}

In large scale and medium scale industries the dysfunctional employee turnover is considered as costlier than the functional employee turnover in terms of loss of knowledge base of the organization (Siebert, W. S., and Zubanov, N. 2009). It is shown in empirical studies that on an average employees switches every six year (Stovel, M., and Bontis, N. 2002). It is important for the organization to find out the reasons for such frequent changes by the employee. So that, the management shall comes up with some effective retention strategies (Samuel, M. O., and Chipunza, C. 2009).

\section{Criteria influencing dysfunctional turnover}

Voluntary turnover occurs due to negative work environment and the attractive opportunities given by the competitive organizations (McElroy et al., 2001). Continuous supervisory support also makes an employee to stay and performer better (Brunetto $Y$ and Farr-Wharton R 2002). Pay act as the motivator to retain the employees (Gardner et al., 2004). Organization needs talented employees to gain the competitive advantage and employees all the time look for career development opportunities in the organization (Prince 2005). As per the research of Henry Ongori (2007) employees are considered as long-term investment of an organization and they should be encouraged by providing job restructuring, work autonomy and empowerment. Hytter (2007) found that factors like organizational commitment, loyalty and organization attachment have direct sway on employee's intension to stay. However the factors like rewards, leadership style, work life balance, Training \& Development, physical working condition have indirect influence on the intension of the employee to stay in the organization. Bhatnagar (2007) suggested that work tasks, career growth, learning and development, relationship with supervisor, fair pay and supportive management shall help in reducing the stress of employees and hence enables the management to retain them.
Compensation may not be considered as one of top factor in influencing employee turnover but is critical factor in reducing turnover and enhancing organizational commitment (Moncraz et al., 2009). An employee stays or leaves the organization depending upon the level of Job satisfaction they feel and the commitment of the organization (Shahnawaz, M. G., and Jafri, M. H. 2009). As per the past literature organizational justice, ambiguity and conflict in role and cynicism are the reasons of employee burnout and which in turn leads to job dissatisfaction and exit from the organization (Yener, D., and Tolgas, D. 2014). According to the World Bank report logistics job has been unattractive due to unpleasant work environment and hard core labour work. Also the report says providing healthy work environment, opportunity to grow, transparent career path, rewards and recognition, a good pay, proper training opportunities and the supervisory concern may help the organization to make their key managers to stay and work efficient in the organization (McKinnon et al., 2017).

\section{Models suggested for retaining efficient employees}

\subsection{Job Embeddedness Model}

The model was given by Mitchell and group in 2001 which suggested that any organization needs to support its efficient employees inside as well as outside the organization. That is organization needs to work in the direction of following three dimensions namely links, fit and sacrifice to build the team. Links helps in building stronger connections among the employees and between the employee and the organization. This could be achieved by introducing mentoring system, team activity sponsorship, reinforcing team identities, etc. Fit dimension enables an organization to recruit a person who is fit for the job from all angles. That is an employee who fits with the organizational culture and value system, and reciprocally the job fits with the employees' basic need of balance between his work and life. Sacrifice dimension wants a company 


\begin{tabular}{|c|c|c|}
\hline Dimensions & Organization Support - Inside & Organization Support - Outside \\
\hline \multirow{3}{*}{ Links } & Mentoring & $\begin{array}{l}\text { Organizational support for community-based } \\
\text { service }\end{array}$ \\
\hline & Accomplishments recognition & \multirow{2}{*}{ Employees team activity sponsership } \\
\hline & Reinforce Team Identities & \\
\hline \multirow[b]{2}{*}{ Fit } & Fit with job hiring & Local recruitment - minimize relocation \\
\hline & $\begin{array}{l}\text { Fit with the organizational culture and values } \\
\text { hiring }\end{array}$ & $\begin{array}{l}\text { Work-life balance program(e.g. flextime, job } \\
\text { sharing) }\end{array}$ \\
\hline \multirow[b]{2}{*}{ Sacrifice } & Provide financial incentives & Promotion without transfer \\
\hline & $\begin{array}{l}\text { Provide nonfinancial incentives (e.g. } \\
\text { sabbaticals or unique perks) }\end{array}$ & Assistance in home buying \\
\hline
\end{tabular}

Source: (Mitchell et al., 2001)

Figure 1: Job Embeddedness suggestions by dimensions for employee retention

to provide financial and non financial help to the employee and help to reduce the burden of physiological needs.

\subsection{Communication Model}

\begin{tabular}{|c|c|c|}
\hline Communication Satisfaction & Job Satisfaction & Retention of efficient older workers \\
\hline \multicolumn{3}{|l|}{$\sqrt{t}$} \\
\hline Communication field & Communication Subject & Benefits and Results of Communication \\
\hline $\begin{array}{l}\text { Changing employers-employees } \\
\text { mental models }\end{array}$ & $\begin{array}{l}\text { Consequences of population ageing, characteristics of } \\
\text { the culture of age-friendly organization, succession } \\
\text { management }\end{array}$ & $\begin{array}{l}\text { Increasing awareness about age-friendly organization. } \\
\text { Promotion and implementation of age management strategies }\end{array}$ \\
\hline Knowledge management & $\begin{array}{l}\text { Additional education and training needed, } \\
\text { knowledge transfer, knowledge recovery }\end{array}$ & Keeping older workers' skills up-to date. \\
\hline $\begin{array}{l}\text { Health management and work place } \\
\text { management }\end{array}$ & $\begin{array}{l}\text { Health prevention, safety at work, work loads, healthy } \\
\text { work environment, restructuring of job positions, } \\
\text { alternative career paths, and flexible forms of } \\
\text { employment. }\end{array}$ & $\begin{array}{l}\text { Increased job satisfaction, dedication and organizational commitment that } \\
\text { lead to higher inclination to stay at work. }\end{array}$ \\
\hline Reward system & $\begin{array}{l}\text { The right mix of rewards (the base pay, a variable part } \\
\text { of the salary, and benefits, as well as the psychological } \\
\text { perception of work - the psychological contract). }\end{array}$ & $\begin{array}{l}\text { When older employees feel that they are not well rewarded and the } \\
\text { psychological contract between the employer and employees is shaky, } \\
\text { employees will consider opportunities for early retirement. Personalizing } \\
\text { rewards to suit the individual! }\end{array}$ \\
\hline Management of different generation & $\begin{array}{l}\text { Discussing generational differences; conflicts that } \\
\text { arise from generation differences. }\end{array}$ & $\begin{array}{l}\text { The optimal age structure while avoiding generational conflicts through } \\
\text { quality communication. }\end{array}$ \\
\hline \multirow[t]{2}{*}{ Retirement planes } & \multirow{2}{*}{$\begin{array}{l}\text { The financial security, the mix of skills and } \\
\text { opportunities for workers; expertise that should be } \\
\text { kept within the business beyond retirement; the } \\
\text { retirement process that should be built into career } \\
\text { planning in the future, phased retirement models and } \\
\text { employee "preparedness for life after retirement. }\end{array}$} & Management is protected from sudden shortages in staff or skills. \\
\hline & & $\begin{array}{l}\text { When communication ideally flows, both - manager and an employee - have } \\
\text { time to prepare for retirement. }\end{array}$ \\
\hline Leadership & Leadership styles, trust, respect. & Improving relations between management and employees. \\
\hline Key barriers to employee retention & $\begin{array}{l}\text { Age discrimination, problems with approval for } \\
\text { on-thejob education and training, inability to ensure } \\
\text { work-life balance, and health problems. }\end{array}$ & Combating age barriers and enabling age-friendly working environment. \\
\hline \multirow[t]{3}{*}{ Communication satisfaction } & \multirow{3}{*}{$\begin{array}{l}\text { Satisfaction with communication climate; satisfaction } \\
\text { with communication with supervisors; satisfaction } \\
\text { with organizational integration; satisfaction with } \\
\text { media quality; satisfaction with horizontal and } \\
\text { informal communication; satisfaction with } \\
\text { organizational perspective; satisfaction with } \\
\text { communication with subordinates; and satisfaction } \\
\text { with personal feedback. }\end{array}$} & The formation of affinity groups of older employees. \\
\hline & & Good relations between all employees. \\
\hline & & $\begin{array}{l}\text { Communication satisfaction improves job satisfaction and commitment which } \\
\text { lead to loyalty and higher inclination towards prolonging working life. }\end{array}$ \\
\hline
\end{tabular}

Source: (Znidaric et al., 2011)

Figure 2: Communication model for employee retention 
Communication model suggested that employees shall work happily with the organization, if their job expectations are met and they are truly satisfied with their job. However, the job expectations differ from individual to individual and should be identified by properly communicating with them. The communication model include steps from identifying various parameters of job satisfaction; discussing content of each parameter with the employees through various channels of communication like verbal and non-verbal; taking and giving feedbacks. The communication should be frequent and should address the issues and solutions to the issues discussed. This model helps in increasing the communication satisfaction leading to increase in job satisfaction, which ultimately leads to locality and long term relationship of an efficient employee and employer.

\subsection{Employee Retention \& Job Satisfaction model}

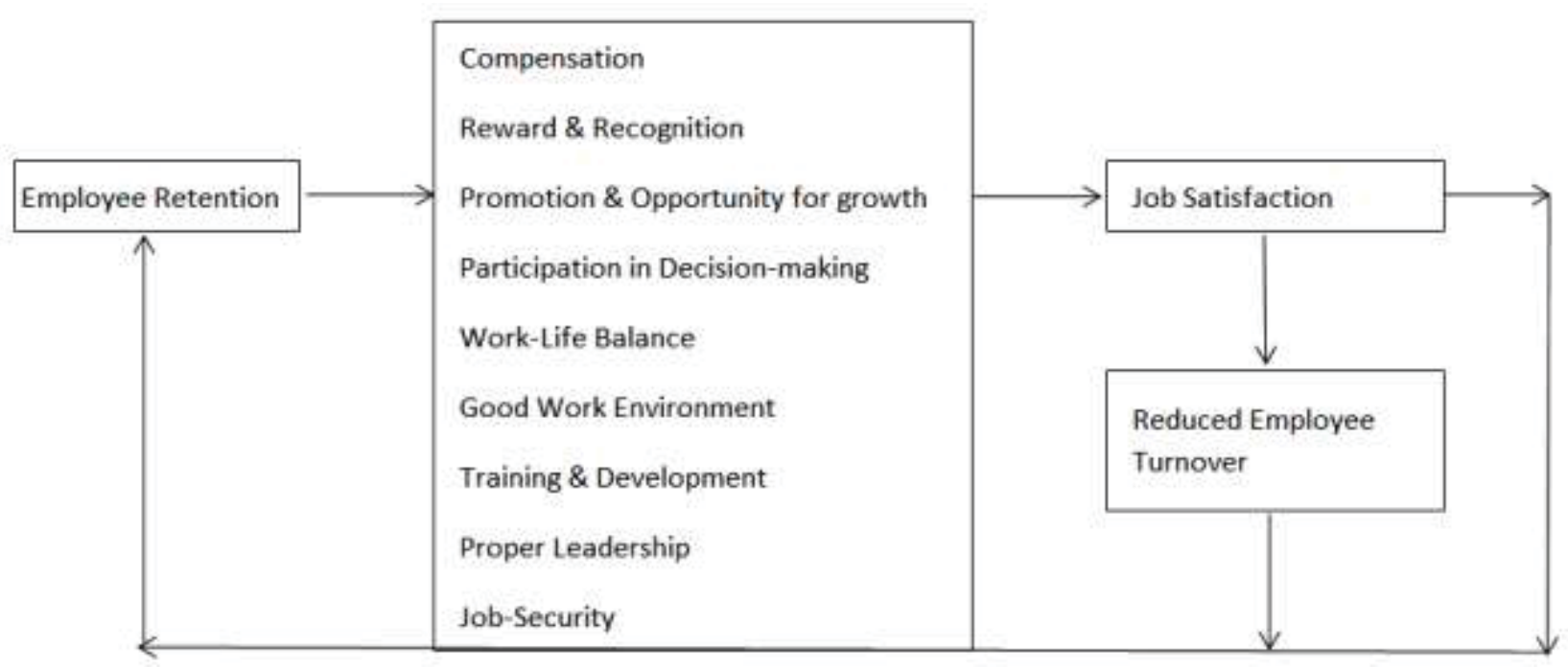

Figure 3: Employee retention and job satisfaction model

Source: (Bidisha, L. D and Mukulesh, B. 2013)

Employee retention and job satisfaction goes hand in hand. As per the model given by Bidisha and Mukulesh (2013), job satisfaction is directly proportional to employee retention and negatively correlated to employee turnover. The model suggests that if the organization takes good care of the above given retention factors, it will not only help in retaining the existing talent but obviously will attract new talent into the organization.

\subsection{Deloitte Engagement Model}

As per the report of Deloitte (2015), an employee should be engaged in the organization by providing work with some meaning, hands-on management, positivity in working environment, growth opportunity and trust in leadership. Increase in engagement level increases the commitment and loyalty of an employee and employer towards each other, which in turns helps in retaining the talent in the organization. 
Deloitte Engagement Model

\begin{tabular}{|c|c|c|c|c|}
\hline Meaningful work & Hands-on management & $\begin{array}{l}\text { Positive work } \\
\text { environment }\end{array}$ & $\begin{array}{c}\text { Growth } \\
\text { opportunity }\end{array}$ & Trust in leadership \\
\hline \multicolumn{5}{|c|}{$2 \sqrt{2}$} \\
\hline Autonomy & Clear, transparent goals & $\begin{array}{l}\text { Flexible work } \\
\text { environment }\end{array}$ & $\begin{array}{c}\text { Training and } \\
\text { support on the job }\end{array}$ & Mission and purpose \\
\hline Select to fit & Coaching & $\begin{array}{l}\text { Humanistic } \\
\text { workplace }\end{array}$ & $\begin{array}{l}\text { Facilitated talent } \\
\text { mobility }\end{array}$ & $\begin{array}{l}\text { Continuous } \\
\text { investment in people }\end{array}$ \\
\hline $\begin{array}{c}\text { Small, empowered } \\
\text { teams }\end{array}$ & $\begin{array}{c}\text { Invest in management } \\
\text { development }\end{array}$ & $\begin{array}{l}\text { Culture of } \\
\text { recognition }\end{array}$ & $\begin{array}{l}\text { Self-directed, } \\
\text { dynamic learning }\end{array}$ & $\begin{array}{c}\text { Transparency and } \\
\text { honesty }\end{array}$ \\
\hline Time for slack & $\begin{array}{l}\text { Modern performance } \\
\text { management }\end{array}$ & $\begin{array}{l}\text { Inclusive, diverse } \\
\text { work environment }\end{array}$ & $\begin{array}{l}\text { High impact } \\
\text { learning culture }\end{array}$ & Inspiration \\
\hline
\end{tabular}

Figure 4 Deloitte Engagement model for employee retention

Source: (Bersin, J. 2015)

\section{RESEARCH GAP}

As per the review of literature, primarily following criteria were observed namely ambiguity, attractive opportunities, career development, conflict in role, continuous supervisory support, cynicism, empowerment, fair pay, job restructuring, job satisfaction, leadership style, learning and development, loyalty, negative work environment, organizational attachment, organizational commitment, organizational justice, Physical working conditions, relationship with supervisor, rewards and recognition, supportive management, Training \& Development, work autonomy, work life balance, work tasks, etc,. But these criteria need to be checked for overlapping and trade-off to avoid the redundancy and get the precise influence of criteria on employee retention. Also, the models used for employee retention lacks the action plan for implementation of the same in the organization.

\section{RESEARCH OBJECTIVE}

1. To study and evaluate the factors affecting employee retention.

2. To study and select the employee retention model implemented to retain efficient employees in the organization.
3. To evaluate the before and after effect of implemented model on employee's preference to stay or quit the organization.

\section{RESEARCH METHODOLOGY}

The research methodology was chosen with utmost care as this research involves assessing the multiple factors forcing employees to quit. Complete methodology starting data collection to implementing tools and techniques is discussed in subsections.

\section{Sampling and Data collection}

As per the literature review and in-depth interview with 10 experts of the industry, major criteria which influences the employee decision to choose alternative of performing efficiently, forced stay i.e. absenteeism or leave the organization were short listed. Experts were industry professionals with minimum 10 years of experience and holding designation of general manager or vice president and above in HR functions of logistics companies.

3 employees of 10 logistics organizations each were taken as sample. Selected logistics organizations have their working facilities located all over the 
India. Questionnaire based structure interviews containing paired comparison of 8 criteria with respect to the goal and paired comparison of 3 alternatives with respect to each criterion had been administrated to the sample. Multiple criteria decision making tool called Analytical Hierarchy Process (AHP) was used to evaluate the preference of criteria and their influence on employees' decision of forced stay; exit or perform well in the organization.

\section{Finalizing employee retention mode and implementation}

Grouped preference of 30 efficient employees for each criterion evaluated was listed to choose and implement the efficient employee retention model. Velocity Model of Efficiency (VME) given by the authors was implemented in two selected organizations. The model contains action plans to improve the dysfunctional employee retention. After implementation of the model, preferences of alternatives with respect to the criteria in both the organizations were checked. That is, previously selected 3 efficient employees of each organization were asked to rank the preference of performing efficiently, forced stay i.e. absenteeism or leave the organization with respect to the facility provided by the organization through VME.

\section{Conceptual framework}

As per the review of literature and focus group interview with expert of the logistics industry, 8 criteria were selected. The conceptual framework (Figure 5) of this study assumes eight criteria namely Career development, Compensation, Motivation, Organization Commitment, Senior Subordinate Relationship, Training \& Development, Work Life Balance and Working Environment which may influences the employee decision of working efficiently, stay absent or to exit the organization.
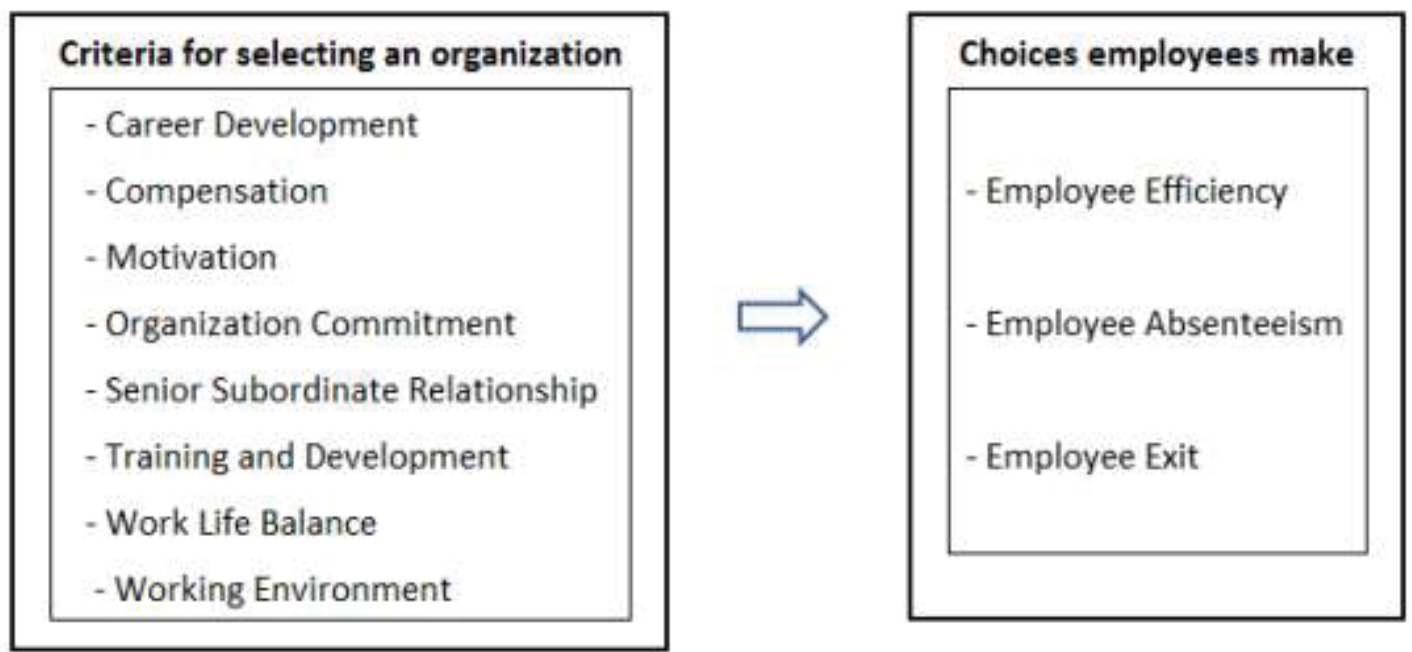

\section{Employee retention model}
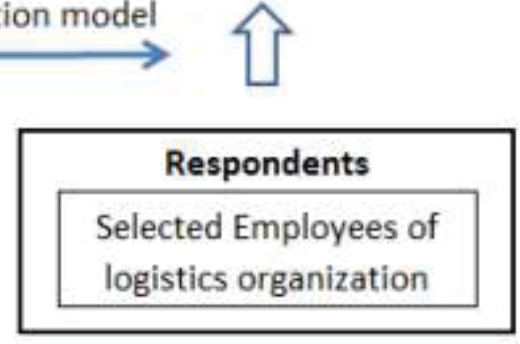

Figure 5: Conceptual framework for accessing influence of criteria on alternatives 


\section{RESEARCH TOOL AND THE MODEL}

\section{Analytical Hierarchy Process (AHP)}

Thomas Saaty (1980) introduced an effective tool called Analytical Hierarchy Process (AHP), which is a multi-criteria decision making tool. It was used by organizations, institutes and other managements to deal with the complex decision making. AHP helps the decision makers to set priorities, reduce complex problem or decision into simpler by the method of pairwise comparison and normalizing the results. AHP helps in capturing both objective and subject aspects of a decision. Analytical Hierarchy Process (AHP) is a model which helps managers to understand the trade-offs between environmental dimensions (Handfield et al., 2002). Further, AHP also check the consistency of the assessment of the decision maker and hence can reduce the biasness in the decision making process (Hadadian, A. R., and
Rasoulian, A. 2017). The AHP based approach is used to identify and prioritize critical success criteria so as to evaluate the performance levels.

Analytical Hierarchy Process (AHP) is based on four steps: decomposition, comparative judgment, synthesis of priorities (Korpela, J. and Tuominen, M. 1996) and decision making. The important step in using AHP is to develop a hierarchy by decomposing the problem down into its relevant components. Three levels of hierarchy: the goal, criteria and alternative were used. All the elements are assumed to be mutually independent.

Step 1: Decomposition involves arranging the problem into Goal, criteria and alternatives (Figure 6). The goal of this AHP problem was to find the employees preference for staying in any organization.

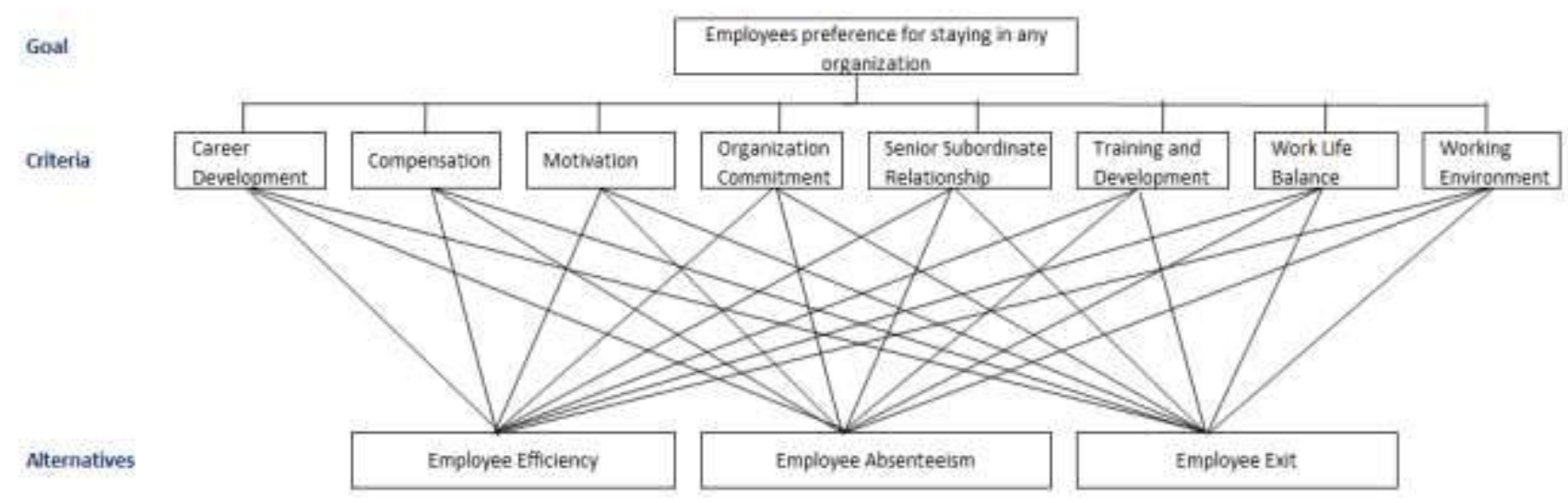

Figure 6: Hierarchical Decomposition of the Problem

Step 2: Comparative judgement involves doing the pair-wise comparisons. The two type of pair-wise comparisons are made first is the pair-wise comparison between pair of criteria with respect to goal which show relative importance of criteria and the second is pair-wise comparison between pairs of alternatives with respect to criteria which shows relative importance of alternatives.

Following scale has been used while making comparisons: 
Table 1: Scale for Comparison

\begin{tabular}{|c|l|l|}
\hline Intensity of importance & \multicolumn{1}{|c|}{ Definition } & \multicolumn{1}{c|}{ Explanation } \\
\hline 1 & Equally Preferred & Two factors contribute equally to the objective. \\
\hline 3 & Moderately Preferred & Experience and judgement slightly favour one over the other. \\
\hline 7 & Strongly Preferred & Experience and judgement strongly favour one over the other. \\
\hline 9 & Very Strongly Preferred & $\begin{array}{l}\text { Experience and judgement very strongly favour one over the } \\
\text { other. Its importance is demonstrated in practice. }\end{array}$ \\
\hline & Extremely Preferred & $\begin{array}{l}\text { The evidence favouring one over the other is of the highest } \\
\text { possible validity. }\end{array}$ \\
\hline
\end{tabular}

As per the reciprocal axiom, if attribute $A$ is extremely preferred over attribute $\mathrm{B}$ and the $\mathrm{A}$ is rated at 9 and $B$ will be rated as 1/9. The comparison of Criteria with itself will remain 1.

Step 3: Synthesis of priorities involves establishing priorities by normalization or prioritization of pairwise comparison matrix. It refers to the process of transforming pairwise comparison matrix into priority or normalized matrix. That is providing each node (Criterion; Alternative) a relative weight from the total (Sum) available in Pairwise Comparison matrix for that respective node. It gives a relative importance for each evaluated Criterion; Subcriterion; Alternative. Priority vector is the average of relative weights of each criterion.

Step 4: For decision making, Maximum Eigen Value " $\lambda \max "$ is calculated as the sum of weights calculated in normalized matrix i.e. sum of $\lambda 1+\lambda 2+\ldots .+\lambda$. It is calculated to find out the consistency of the answer given by participants. The closer $\lambda \max$ (sum of priority is to $\mathrm{n}$ (number of Criteria/Subcriteria/Alternatives), the more consistent the judgments. Thus, the difference, $\lambda$ max-n, can be used as a measure of inconsistency (in case of perfect consistency this difference will be zero). Instead of using this difference directly, Saaty defined a Consistency Index (CI) as:

$$
(\lambda \max -\mathrm{n}) /(\mathrm{n}-1)
$$

Since it represents the average of the remaining eigen values. In order to derive a meaningful interpretation of either the difference or the consistency index, Saaty simulated random pairwise comparisons for different size matrices, calculating the consistency indices, and concluding an average consistency index for random judgments for each size matrix. In the table below the upper row is the order of the random matrix, and the lower is the corresponding index of consistency for random judgements (RI)

Table 2: Random consistency Index table given by Saaty (1980)

\begin{tabular}{|l|c|c|c|c|c|c|c|c|c|c|c|c|}
\hline No. of factors (n) & 1 & 2 & 3 & 4 & 5 & 6 & 7 & 8 & 9 & 10 & 11 & 12 \\
\hline $\begin{array}{l}\text { Random Consistency } \\
\text { Index (RI) }\end{array}$ & 0 & 0 & 0.58 & 0.9 & 1.12 & 1.24 & 1.32 & 1.41 & 1.45 & 1.49 & 1.51 & 1.48 \\
\hline
\end{tabular}


The Consistency Ratio (CR) is calculated to measure the consistency of the judgements relative to large samples of purely random judgements. If the CR is much in excess of 0.1 the judgements are untrustworthy because they are too close for comfort to randomness and the exercise is valueless or must be repeated. It is a comparison between Consistency
Index and Random Consistency Index (RI), or in formula: $\mathrm{CR}=\mathrm{CI} / \mathrm{RI}$

Random Index is the average value of CI for random matrices using the Saaty scale (Saaty, T.L. 1980).

\section{Velocity Model of Efficiency (VME)}

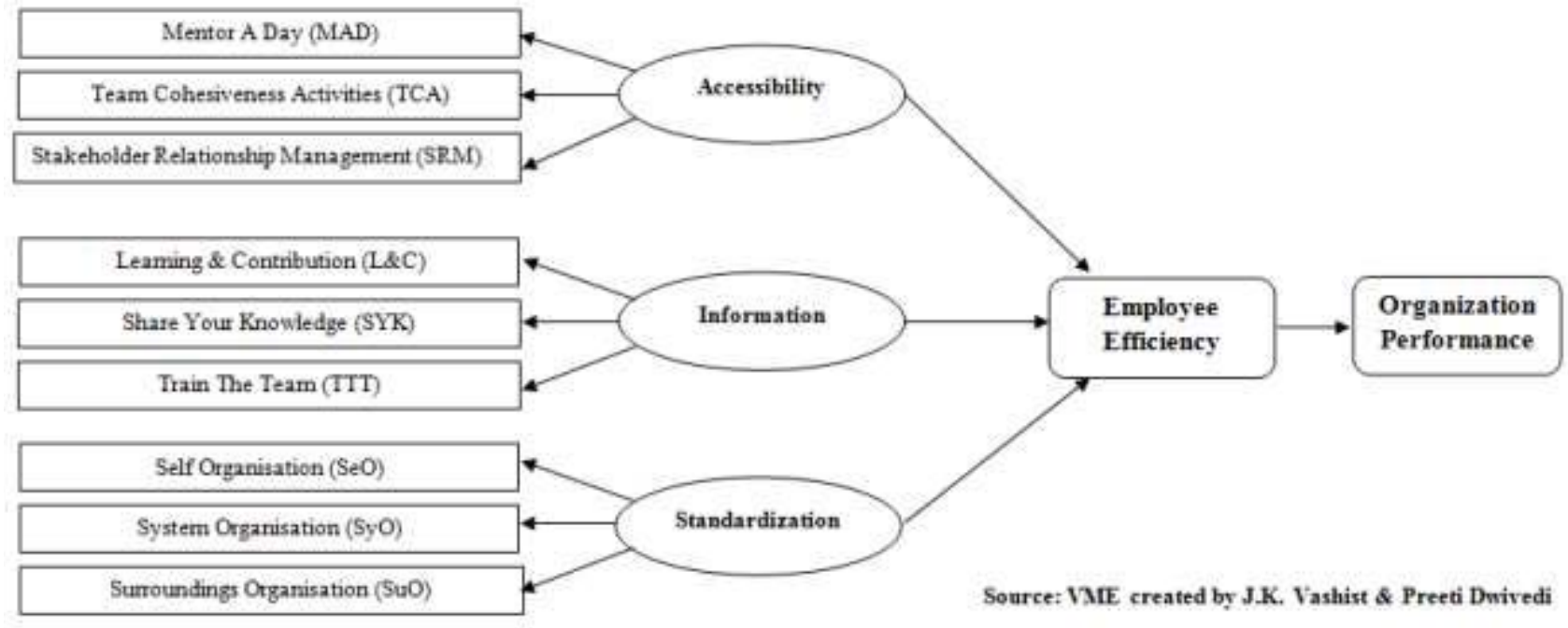

Figure 7: Velocity Model of Efficiency (VME)

Source: (Kishore Vashist J. and Dwivedi P. 2017)

Kishore and Dwivedi (2017) gave a model containing action plans for improving factors which influences an employee to exit the organization. Action plans mainly focuses on three dimensions, that is, increasing the accessibility among the stakeholders of the organization to improve the relationship with external stakeholders (customers, vendors and other institutions) as well as the internal stakeholders (subordinates, peers and supervisors); suggest the method of acquiring the correct quality and quantity of information and the use of the same; standardization of self, system and surroundings to promote the ease of work. Velocity Model of Efficiency (VME) works in the direction of motivating and making the employees to work with efficiency and hence improving their level of satisfaction in terms of knowledge and skill upgradation. An organization can engage and retain its employees by implementing the action plans suggested in the model. The model helps in improving the employee efficiency, which leads to improvement in the performance of the organization.

\subsection{Accessibility}

The model says there should be 360 degree accessibility among all the stakeholders, without any inhibition. Stakeholders refer to internal and external stakeholders. Internal stakeholders are considered as employees' subordinates, peers and supervisors. External stakeholders are considered as customers, vendors and other regulatory authorities. Accessibility can be achieved by implementing following methods: 
2.1.1 Mentor A Day also refer as MAD: A method to boost cross-departmental synergies

2.1.2 Team Cohesiveness Activities also refer as TCA: It is a method to build strong teams

\subsubsection{Stakeholder Relationship Management also} refer as SRM: It is a method to boost trust, care and mutual understanding among the team members

\subsection{Information}

VME model suggest that one should contain correct and updated information \& plan for use of that information. As per the model, there should be optimal value and quantity of information. To get quantity with quality of information following method should be followed:

2.2.1 Learning \& Contribution also refer as L\&C: It is a method to evaluate the gathered knowledge and reckon the significance for achieving the common objective.

2.2.2 Share Your Knowledge also refers as SYK: It is a method to propagate the quality information.

2.2.3 Train The Team also refer as TTT: It is a method to transmit the expertise of individuals among the team

\subsection{Standardization}

VME says, standardization is the process of reducing irregularity, removing redundancy and reducing response time for any action. Standardization is a continuous process and should be done in ways:

\subsubsection{Self Organization also refer as SeO: It is a} method which help individuals to organize them as per the VME format
2.3.2 System Organization also refer as SyO: It is a method which help individuals to organize their system as per the VME format

\subsubsection{Surroundings Organization also refer as} SuO: It is a method which help individuals to organizes their surroundings as per the VME format

\section{ANALYSIS AND RESULTS}

This section summarizes the finding with construction of prioritization matrices for criteriagoal and criteria-alternatives. The criteriaalternatives matrices were made before and after the implementation of employee retention model to measure the change. The pair-wise comparison was normalized to evaluate the ranking of each criterion and alternatives.

\section{Prioritization/Normalization of criteria with respect to goal}

The Criteria were compared as to how important they are to the decision makers, with respect to the goal and then prioritized/normalized to find the ranking. Table 3 shows the comparison of each criterion with one another with respect to the goal of employees' intension to perform efficiently, stay absent or exit the organization. There are total 28 pairs to be compared (i.e. Training \& Development/Compensation, Training \& Development/ Working Environment, Training \& Development/Organization Commitment, Training \& Development/Work life balance, Training \& Development/Senior and subordinate relationship, Training \& Development/Career Development, Training \& Development/Motivation, likewise one criterion with all others). 
Table 3: Prioritization/Normalization of criteria with respect to goal

\begin{tabular}{|c|c|c|c|c|c|c|c|c|c|c|c|}
\hline \multicolumn{12}{|c|}{ Pribeity Vector level 2 with respied to Goal } \\
\hline Criterila & $\begin{array}{l}\text { Training and } \\
\text { Devetopment }\end{array}$ & Compensation & $\begin{array}{c}\text { Working } \\
\text { Enviconment }\end{array}$ & $\begin{array}{l}\text { Orgmization } \\
\text { coemmitment }\end{array}$ & Work life batance & $\begin{array}{l}\text { Servier: } \\
\text { Subardinete } \\
\text { Melationutip }\end{array}$ & $\begin{array}{c}\text { Creer } \\
\text { Development }\end{array}$ & Motivation & $\begin{array}{l}\text { Pribeity } \\
\text { Vector }\end{array}$ & $\begin{array}{l}\text { Wit Sum } \\
\text { vector }\end{array}$ & Fank \\
\hline $\begin{array}{l}\text { Training and } \\
\text { Development }\end{array}$ & $a 0000$ & 0.0661 & 0.1102 & 0.0685 & $0 \pm 061$ & 0.0538 & 0.0683 & 0.0455 & 00796 & 0.6026 & 7 \\
\hline Compenistion & 0.0209 & 0.0852 & 00018 & 0.0982 & 0.0244 & 0,0750 & 0.0728 & 0.2010 & a.ca73 & $0.7+8 y$ & 3 \\
\hline $\begin{array}{l}\text { Working } \\
\text { frivironment }\end{array}$ & 0.0376 & $0.061 \mathrm{~T}$ & 0.0593 & 0.0685 & 0.0433 & 0.0660 & 0.0850 & acos 30 & 0.0594 & 0.4869 & 8 \\
\hline $\begin{array}{l}\text { Organization } \\
\text { commitment }\end{array}$ & 0.0730 & 0.0621 & 0.0618 & 0,0715 & 0.0587 & 0,0684 & 0,0759 & 0.1284 & 0.0750 & 0.6172 & 6 \\
\hline Work iffe balance & 0.1323 & 0.1813 & 0.2733 & 0.2699 & 0.2000 & 0.2745 & Q1916 & 0.1987 & 0.2042 & 1.6784 & 2 \\
\hline $\begin{array}{l}\text { Senion-Subordinate } \\
\text { Nelotionshis }\end{array}$ & 0.2226 & 0.1964 & 0.1336 : & 0.1789 & 0.2247 & 0.1711 & 0.1783 & 0.2275 & 0.1814 & 2.4996 & s \\
\hline $\begin{array}{l}\text { Careet } \\
\text { Development }\end{array}$ & 0.2422 & 0.2767 & 0.1649 & 0.2226 & 0.2472 & 0.2267 & 0.2364 & 0.2210 & 02297 & 1.5891 & 1 \\
\hline Motivation & 0.1921 & 0.0725 & 0.0044 & 0.0478 & 0.257 & 00646 & 00019 & 0.0559 & 0.0994 & 0.7333 & 4. \\
\hline \multicolumn{2}{|c|}{ Maxituman Eqen Value (Lamoda) } & a.22 & \multicolumn{2}{|c|}{ No af Comparison $(n)$} & 8 & \multicolumn{2}{|c|}{ Cansiblency index (CO) } & 0.0314 & \multicolumn{2}{|c|}{$\begin{array}{l}\text { Handom Cansistency } \\
\text { index (Ri) }\end{array}$} & 1.41 \\
\hline \multicolumn{2}{|l|}{ Comistency hatio $(\mathrm{CH})$} & 0.02224 & $<$ & 0.1 & Consktent & & & & & & \\
\hline
\end{tabular}

Ranking shows that employees prefer career development followed by work-life balance, seniorsubordinate relationship, motivation, compensation, organization commitment, Training \& Development and working environment.

2. Prioritization/Normalization of the Alternatives with respect to the Criteria before model implementation
Table 4 shows the preference of employees to work efficiently; with absenteeism or to exit the organization with existing facilities provide by the organization. Evaluation was done before the implementation of VME model. That is efficient employees were asked to rank their preference of working in the organization on the basis of existing employee development or retention strategies followed by the organization.

Table 4: Prioritization/Normalization of alternatives with respect to criteria before model implementation

\begin{tabular}{|c|c|c|c|c|c|c|c|c|c|c|}
\hline \multicolumn{11}{|c|}{ Factors impacting employee retention } \\
\hline Aiternatives Criteris & $\begin{array}{l}\text { Training and } \\
\text { Development }\end{array}$ & Compentention & $\begin{array}{l}\text { Workins } \\
\text { Environment }\end{array}$ & $\begin{array}{l}\text { Organization } \\
\text { commitment }\end{array}$ & $\begin{array}{l}\text { Work lite } \\
\text { balance }\end{array}$ & $\begin{array}{l}\text { Senior } \\
\text { Subordinate } \\
\text { Relationahip }\end{array}$ & $\begin{array}{c}\text { Career } \\
\text { Development }\end{array}$ & Motivation & $\begin{array}{l}\text { Prierity } \\
\text { Vector }\end{array}$ & Rank \\
\hline Eflicient Employee & 0.38 & 0.15 & 0.15 & 0.15 & D. 28 & 0.27 & 0.29 & 0.46 & 0.25 & 3 \\
\hline Imployee Exit & 0.38 & 0,63 & 0,43 & 0.63 & 0.59 & 0.41 & 0.46 & 0.32 & 0.48 & 1 \\
\hline Employee Absenteeism & 0.23 & 0.22 & 0.42 & 0.22 & 0.23 & 0.31 & 0.25 & 0.27 & 0.26 & 2 \\
\hline
\end{tabular}

Ranking shows that most of the employees would like to exit or stay away from the work. Decision was mainly influenced by low compensation, poor organization commitment, no work life balance, no career development, unhealthy working environment and strain in senior-subordinate relationships.

\section{Prioritization/Normalization of the Alternatives with respect to the Criteria after model implementation}

After the implementation of Velocity Model of Efficiency (VME), the alternatives were again compared to each other as to how important they are to the decision maker with respect to each criterion. 
Table 5: Prioritization/Normalization of alternatives with respect to criteria after model implementation

\begin{tabular}{|c|c|c|c|c|c|c|c|c|c|c|}
\hline \multicolumn{11}{|c|}{ Factors impacting employee retention } \\
\hline Alternatives & $\begin{array}{l}\text { Training and } \\
\text { Development }\end{array}$ & Compensation & $\begin{array}{l}\text { Working } \\
\text { Environment }\end{array}$ & $\begin{array}{l}\text { Organization } \\
\text { commitment }\end{array}$ & $\begin{array}{l}\text { Work life } \\
\text { balance }\end{array}$ & $\begin{array}{l}\text { Senior: } \\
\text { Subordinate } \\
\text { Relationship }\end{array}$ & $\begin{array}{c}\text { Career } \\
\text { Develepment }\end{array}$ & Metivation & $\begin{array}{l}\text { Prionity } \\
\text { Vector }\end{array}$ & Rank \\
\hline Efficient Employee & 0.80 & 0.69 & 0.71 & 0.70 & 0.70 & 0.71 & 0.73 & 0.74 & 0.72 & 1 \\
\hline Employee Exit & 0,10 & 0.15 & 0.14 & 0.15 & 0.17 & 0.14 & 0.16 & 0.13 & 0.14 & 2 \\
\hline Employee Absenteeism & 0.10 & 0.16 & 0.14 & 0.16 & 013 & 0.14 & 0.11 & 0,13 & 0.13 & $\exists$ \\
\hline
\end{tabular}

Table 5 shows that after the implementation of the model the decision of the employees to exit or stay absent was changed. Employees felt that issues related Training \& Development, compensation, working environment, organization commitment, work life balance senior-subordinate relationship, career development and motivation were addressed and resolved.

\section{DISCUSSION AND CONCLUSION}

This research paper focuses on evaluating the criteria responsible for dysfunctional employee turnover and finding the criteria preferred by the efficient employees. It is a myth that compensation is given the highest priority by the high performing employees. However as per the research, top preferred factors were career development followed by work-life balance, senior-subordinate relationship and motivation while the compensation was ranked at fifth place. Also as suggested in VME model, an induction of appropriate treatment on the employees changes the preference of high performing employees from exit to perform efficiently. Though the model was not focusing on improving the compensation strategies, but still the score of compensation was improved, since the employees were satisfied with their overall growth in the organization. There was substantial increase in the cross-functional synergies, resolving team conflicts, enhancement of trust, care and mutual understanding among the team members. Employees also felt that there was upgradation in their knowledge and skills and they could use it in better ways. The model also helped employees in standardizing self, system and surroundings. VME model can improve the employee retention level of the organization, if implemented across the organization.

\section{IMPLICATIONS}

This research will have more practical implications than the theoretical one. VME model implemented prescribes the methods for improving the dysfunctional employee turnover. Finding of this study will help the employers to focus on developing and implementing economically feasible strategies. VME model is developed keeping in mind the preference of efficient employees. An efficient person focuses on knowledge, skill and career enhancement instead of pay and incentives. Action plans suggested in the model are very easy to implement and can benefit the organization as well as the employees in long run. This research may also help in teaching practical cases in the educational institutions.

\section{LIMITATION AND DIRECTIONS FOR FUTURE RESEARCH}

The research was conducted on the selected efficient employees, therefore, results cannot be generalized to all the employees working in same or different industries. Since the survey was conducted immediate after the implementation of the model, satisfaction level of the employees may change if not implemented continuously and in correct way. Also since the model has not included action plan for compensation criteria, employees' preference of working with the same organization may change, if action plan for compensation or any other monetary 
benefit will not be included in the model. The action plans should be up-graded with time to keep pace with employee retention models of competitive organizations. A longitudinal study can be conducted to capture the variation in the preference of criteria with time. The study should be conducted in various industries and with more sample size to test the applicability of the employee retention models.

\section{REFERENCES}

1) Bersin, J. 2015, 'Becoming irresistible-A new model for employee engagement', Deloitte Review, no. 16, pp. 146-163.

2) Bhatnagar, J 2007, 'Talent management strategy of employee engagement in Indian ITES employees: key to retention', Employee relations, vol 29, no. 6, pp. 640-663.

3) Bidisha, L. D and Mukulesh, B. 2013, 'Employee Retentio: A review of literature', IOSR Journal of Business and Management, vol 14, no. 2, pp. 816.

4) Brown, P., Fraser, K., Wong, C. A., Muise, M., and Cummings, G. 2013, 'Factors influencing intentions to stay and retention of nurse managers: a systematic review', Journal of Nursing Management, vol 21, no. 3, pp. 459-472.

5) Brunetto $Y$ and Farr-Wharton $R$ 2002, 'Using social identity theory to explain the job satisfaction of public sector employees', International Journal of Public Sector Manage, vol 15, no. 7, pp. 534-55.

6) Dalton, D. R., Krackhardt, D. M., and Porter, L. W. 1981, 'Functional turnover:An empirical assessment', Journal of applied psychology, vol 66, no. 6, p. 716.

7) Donoghue, C, 2010, 'Nursing home staff turnover and retention: An analysis of national level data', Journal of Applied Gerontology, pp. 29(1), 89-106.

8) Gardner, D. G., Dyne, L., and Pierce, J. L. 2004, 'The effects of pay level on organization-based self-esteem and performance: A field study.',
Journal of Occupational and Organizational Psychology, vol 77, no. 3, pp. 307-322.

9) Giri, D.M.S.and Mrs. Y. Gayatri. 2018, 'An Empirical Study On Employee Retention', International Journal of Advanced Multidisciplinary Scientific Research (IJAMSR ISSN: 2581-4281), vol 1, no. 2, pp. 8-14.

10) Hadadian, A. R., and Rasoulian, A. 2017, 'Using Analytic Hierarchy Process (AHP) for Selecting the Appropriate Country for Economic Integration: Case of Iran's Foreign Trade with OIC Countries', International Research Journal of Finance and Economics, no. 162, pp. 24-32.

11) Handfield, R., Walton, S. V., Sroufe, R., and Melnyk, S. A. 2002, 'Applying environmental criteria to supplier assessment: A study in the application of the Analytical Hierarchy Process', European journal of operational research, vol 141, no. 1, pp. 70-87.

12) Hytter, A 2007, 'Retention strategies in France and Sweden.', The Irish Journal of Management, vol 28, no. 1, pp. 59-79.

13) Keller, S., and Meaney, M., 2017, 'Attracting and retaining the right talent', McKinsey Quarterly, November 2017.

14) Kishore Vashist J. and Dwivedi P. 2017, 'Impact assessment of Velocity Model of Efficiency on Employee Efficiency', Amity Global Business Review, vol 12, pp. 15-21.

15) Korpela, J. and Tuominen, M. 1996, 'Benchmarking logistics performance with an application of the analytic hierarchy process', IEEE Transactions on Engineering Management, vol 43, no. 3, pp. 323-33.

16) McElroy, J. C., Morrow, P. C., and Rude, S. N. 2001, 'Turnover and Organizational Performance: A Comparative Analysis of the Effects of Voluntary, Involuntary, and Reduction-in-Force Turnover', Journal of applied Psychology, vol 86, no. 6, pp. 1294-1299.

17) McKinnon, A., Flöthmann, C., Hoberg, K., and Busch, C. 2017, Logistics Competencies, Skills, and Training: A Global Overview, The World Bank, Washington, DC.

18) Mitchell, T.R., Holtom, B.C. and Lee, T.W., 2001, 
'How to keep your best employees: Developing an effective retention policy', The Academy of Management Executive, vol 15, no. 4, pp. 96-108.

19) Moncraz, E., Zhao, J., and Kay, C. 2009, 'An exploratory study on US lodging properties', organizational practices and employee turnover and retention', International Journal of Contemporary Hospitality Management, vol 21, no. 4 , pp. $437-458$.

20) Ongori, H, 2007, 'A review of the literature on employee turnover', African Journal of Business Management, pp. 049-054.

21) Prince, BJ 2005, 'Career-focused employee transfer processes.', Career Development International, vol 10, no. 4, pp. 293-309.

22) Saaty, T.L. 1980, 'The Analytical Hierarchy Process', McGrawHill.

23) Samuel, M. O., and Chipunza, C. 2009, 'Employee retention and turnover- Using motivational variables as a panacea', African journal of business management, vol 3, no. 8, pp. 410-415.

24) Shahnawaz, M. G., and Jafri, M. H. 2009, 'Job attitudes as predictor of employee turnover among stayers and leavers-hoppers', Journal of Management Research, vol 9, no. 3, pp. 159-166.

25) Siebert, W. S., and Zubanov, N. 2009, 'Searching for the optimal level of employee turnover: A study of a large UK retail organization', Academy of Management Journal, vol 52, no. 2, pp. 294-313.

26) Stovel, M., and Bontis, N. 2002, 'Voluntary turnover: knowledge management-friend or foe?', Journal of intellectual Capita, vol 3, no. 3, pp. 303-322.

27) The Economic Times 2018, viewed July 2018, <https://economictimes.indiatimes.com/indust ry/transportation/shipping-/-transport/indiaslogistics-sector-to-reach-usd-215-bn-by-2020survey/articleshow/62693817.cms>.

28) Wallace, J., and Gaylor, K. P. 2012, 'A study of the dysfunctional and functional aspects of voluntary employee turnover', SAM Advanced Management Journal, vol 77, no. 3, pp. 27-36.

29) Yener, D., and Tolgas, D. 2014, 'The effects of burnout on organizational commitment in logistics sector', Journal of Business Research Turk, vol 6, no. 2, pp. 15-25.

30) Znidaric, J., Penger, S. and Dimovski, V., 2011, 'Should I stay or should I go: The role of communication in striving to retain older employees', International Journal of Management and Information Systems, vol 15, no. 4 , pp. 1-12. 